\title{
Nilai Siri' dan Pesse dalam Kebudayaan Bugis-Makassar, dan Relevansinya terhadap Penguatan Nilai Kebangsaan
}

\author{
Muhamad Hadis Badewi \\ Sekolah Tinggi Ilmu Ekonomi Muhammadiyah, Palopo - Indonesia
}

\begin{abstract}
The presence of cultural values in each ethnic group is a inevitability, and certainly has a large contribution to the strengthening of national values in Indonesia, so the culture held by the BugisMakassar community, which is trying to be explored in this article. Siri' and pesse are the two main values in the Bugis-Makassar culture, which have the underlying nature of other core values. The question is about the relevance of the values of siri and pesse toward the strengthening value of Indonesian nationality. To answer this question, library research is conducted using qualitative methods. From the research it was found that, siri' and pesse values have strong relevance if they are associated with efforts to strengthen national values in Indonesia, because siri' and pesse are values born from the womb of Indonesian culture, which contain humanity and social solidarity.

Kehadiran nilai budaya pada setiap kelompok etnis adalah sebuah keniscayaan, dan tentunya memiliki sumbangan yang besar terhadap penguatan nilai-nilai kebangsaan di Indonesia, demikian juga halnya dengan budaya yang dimiliki oleh masyarakat Bugis-Makassar, yang berusaha dieksplorasi dalam artikel ini. Siri' dan pesse merupakan dua nilai utama dalam kebudayaan Bugis-Makassar, yang memiliki sifat mendasari nilai-nilai utama lainnya. Pertanyaannya, bagaimana relevansi nilai siri' dan pesse terhadap penguatan nilai kebangsaan Indonesia. Untuk menjawab pertanyaan tersebut, maka dilakukan riset kepustakaan dengan menggunakan metode kualitatif. Dari riset tersebut ditemukan bahwa, nilai siri' dan pesse memiliki relevansi yang kuat jika dihubungkan dengan upaya penguatan nilai kebangsaan di Indonesia, karena siri' dan pesse merupakan nilai yang lahir dari rahim kebudayaan Indonesia, yang mengandung makna kemanusiaan dan kesetiakawanan sosial.
\end{abstract}

Keywords: siri'and pesse; Bugis-Makassar; local wisdom; nationality; value

Korespondensi Penulis: Muhamad Hadis Badewi (emhadis@yahoo.co.id). Sekolah Tinggi Ilmu Ekonomi Muhammadiyah, Jl. Jend. Sudirman Km. 03, Binturu, Kota Palopo, Sulawesi Selatan, Indonesia 91922. 


\section{Pendahuluan}

Setiap kelompok etnis yang hadir di dunia ini, hadir dengan membawa kebudayaannya, yang lahir dari local genius masing-masing, yang terpatri dalam bentuk niliai kehidupan. Hal tersebut juga tergambarkan pada kelompokkelompok etnis yang hidup di Nusantara, termasuk kelompok etnis Bugis-Makassar, yaitu kelompok etnis yang mendiami jazirah Sulawesi bagian Selatan.

Kelompok etnis Bugis-Makassar dalam kehidupannya, membangun sebuah tatanan atau norma dan aturan-aturan adat yang disebut pangngaderreng dalam bahasa Bugis, atau pangngadakkang dalam bahasa Makassar. Mattulada (1995: 54-55) menguraikan, bahwa pangngaderreng dapat diartikan sebagai keseluruhan norma yang meliputi bagaimana seseorang harus bertingkah laku terhadap sesamanya manusia dan terhadap pranata-pranata sosialnya secara timbal balik, sehingga menimbulkan dinamika masyarakat.

Dalam kebudayaan Bugis-Makassar, pangngaderreng atau pangngadakkang yang merupakan keseluruhan sistem norma, di dalamnya terdapat banyak nilai budaya. Sistem norma terungkap baik dalam bentuk naskah kuno, atau yang biasa disebut dengan lontara', maupun dalam bentuk oral tradition atau tradisi lisan. Nilai-nilai yang terdapat dalam kehidupan masyarakat Bugis-Makassar tersebut, jika diuraikan secara teliti maka akan nampak jika terdapat nilai-nilai yang melingkupi nilai-nilai lainnya. Nilai-nilai itulah yang disebut di sini sebagai nilai-nilai utama, dalam hal ini bukan berarti bahwa nilai-nilai yang lain adalah nilainilai yang tidak penting, hanya saja merupakan penjabaran dari nilai-nilai utama.

Nilai-nilai yang mengalir dalam kehidupan keseharian masyarakat Bugis-Makassar menuntut hadirnya keutamaan-keutamaan dalam diri masyarakat Bugis-Makassar agar menjadi manusia yang dituntunkan dalam pangngaderreng. Dalam kebudayaan masyarakat BugisMakassar, terdapat beberapa nilai yang dianggap sebagai nilai-nilai utama. Nilai-nilai utama yang dimaksud tersebut adalah, siri', pesse, lempu', getteng, ada tongeng, dan reso.

Nilai-nilai yang disebutkan di atas, walaupun dikatakan sebagai nilai-nilai uatama, namun dalam hal ini terdapat dua nilai dari keenam nilai tersebut yang merupakan nilai-nilai dasar, kedua nilai tersebut adalah siri' dan pesse. Persoalan ini kemudian menimbulkan pertanyaan, kenapa siri' dan pesse dikatakan sebagai nilai dasar dari nilai-nilai utama dalam kebudayaan masyarakat Bugis-Makassar? Hal itulah yang menjadi pertanyaan paling mendasar dalam pembicaraan tentang nilai dalam kebudayaan Bugis-Makassar, karena siri' dan pesse adalah dua nilai yang senantiasa serangkai, yang menjadi dasar atau penggerak nilai-nilai utama lainnya.

Nilai budaya yang terdapat dalam setiap kelompok etnis, terkadang dipandang negatif, sebagai nilai yang tidak lagi bisa diterapkan dalam jaman globalisasi. Padahal tanpa disadari, jika bangsa sebesar Indonesia sangat membutuhkan nilai-nilai yang lahir dari rahim budaya masyarakat Indonesia sendiri, sangat 
membutuhkan identitas ke-Indonesiaan yang berakar dari budaya yang hidup di Indonesia, yang tentunya harus senantiasa melakukan komunikasi dan interaksi dengan nilai-nilai budaya yang bersumber dari luar agar tidak gagap dalam menghadapi sebuah perubahan. Hal itulah yang tidak bisa dinafikan, bahwa Indonesia lahir dengan ke-Indonesiaannya yang beragam. Ciri khas Indonesia adalah kebangsaan yang terbangun dari keberagaman budaya.

"Kebudayaan dalam suatu bangsa berkembang seiring perubahan zaman, dari kebudayaan tradisional ke peralihan sampai akhirnya menjadi budaya yang modern. Pergeseran kebudayaan ini disebabkan oleh banyak hal, seperti adanya interaksi dan globalisasi. Perubahan kebudayaan pada masyarakat biasanya ada yang disebabkan oleh masyarakat itu sendiri maupun berasal dari masyarakat pendatang" (Gunawan, 2012: 37).

Bertolak dari pemikiran nilai budaya yang hidup dan berkembang di Indonesia, khususnya nilai budaya yang hidup dalam komunitas etnis Bugis-Makassar, dalam hal ini nilai siri' dan pesse, akan menimbulkan pertanyaan, sejauh mana dinamika nilai siri' dan pesse sebagai nilai dasar, dalam kebudayaan Bugis-Makassar, relevan terhadap penguatan nilai kebangsaan Indonesia? Untuk menjawab pertanyaan tersebut, uraian yang diungkap dalam artikel ini didasarkan dari hasil riset kepustakaan yang dilakukan dengan menggunakan metode kualitatif.

Kajian tentang nilai budaya sudah sangat banyak ditemukan di jurnal-jurnal ilmiah dan makalah-makalah seminar, bahkan tidak sedikit juga yang mengkaji tentang nilai siri' dan pesse, yang tentunya berangkat dari berbagai per- spektif. Kajian tentang siri' dan pesse dalam artikel ini berangkat dari perspektif nilai dalam konsep aksiologis. Dengan demikian, bisa dilihat sejauh mana siri' dan pesse sebagai nilai dasar dalam kebudayaan Bugis-Makassar memberikan sumbangsih terhadap upaya penguatan nilai kebangsaan di Indonesia.

\section{Mitos sebagai Salah Satu Sumber Nilai}

Pada prinsipnya, nilai merupakan sebuah kualitas yang tidak pernah hadir kecuali melekat atau mewujud pada sesuatu, tidak melekat pada dirinya sendiri. Karena tidak mampu mewujud ketika tidak ada wadah atau sesuatu tempatnya melekat, maka Frondizi (2007:10) menyebutnya sebagai ada yang bersifat parasitis yang tidak dapat hidup tanpa didukung oleh objek riel, karena nilai adalah kualitas.

Bahasa merupakan salah satu wadah tempat nilai mewujudkan diri. Sebagai wadah, bahasa memiliki keistimewaan, bisa menjadi wadah pengungkapan nilai etis maupun nilai estetis. Nilai estetis mewujud pada bahasa ketika dirangkai menjadi sebuah karya sastra, dan karya sastra pun selain menampilkan nilai estetis, nilai etis pun akan senantiasa hadir. Selain itu, nilai etis juga hadir ketika bahasa dirangkai menjadi petuah, nasihat, maupun menjadi sebuah undang-undang. Dalam hal ini kitab suci juga merupakan rangkaian bahasa yang isinya mengandung nilai-nilai etis.

\section{Mitos La Galigo}

Mitos lahir dari bentuk-bentuk kesadaran masyarakat yang berusaha untuk berpikir dan mengartikulasikan alam dan lingkungannya, yang berarti bahwa mitos merupakan salah satu 
produk budi manusia yang berkesadaran. Mitos tidak pernah dilahirkan dari alam pikiran orang perorang, tetapi merupakan akumulasi dari kesadaran setiap orang dalam sebuah kelompok masyarakat yang intens berinteraksi dengan alam serta lingkungannya. Mitos merupakan objektifitas pengalaman sosial budaya manusia, dan setiap segi pengalaman manusiawi punya kaitan dengan realitas (Cassirer 1987: 117). Mitos memiliki tugas memberikan sebuah justifikasi alamiah kepada kehendak sejarah, dan membuat kemungkinan tampak abadi (Barthes, 2009: 208). Selanjutnya Barthes juga mengungkapkan:

"Apa yang dipasok dunia ke dalam mitos adalah realitas historis, yang didefinisikan oleh cara-cara di mana manusia memproduksi atau menggunakannya, kendati ini pun akan kembali dengan cepat; sedangkan apa yang dikembalikan oleh mitos pada gilirannya adalah citra alamiah dari realitas ini ...... namun, mitos itu sendiri dibentuk oleh hilangnya kualitas historis" (Barthes 2009:208).

Memang ada benarnya jika dikatakan, bahwa mitos adalah sesuatu yang tidak rasional dan bukan sebuah realitas, namun akan ditemukan sebuah jawaban, bahwa pandangan tersebut tidak sepenuhnya benar jika ingin berusaha mencoba untuk memasuki cara pandang dan cara pikir yang dilakukan oleh kelompok masyarakat yang melahirkan mitos. Kehadiran mitos di dunia ini adalah realitas yang tidak terbantahkan, justru yang dianggap sebagai bukan realitas adalah apa yang terdapat dan tergambarkan dalam mitos, namun itu pun bisa dianggap sebagai sebuah realitas, hanya saja telah menjadi realitas yang terselubung, seperti perkataan Malinowski dalam Cassirer (1987: 130), setiap mitos berintikan atau berdasarkan beberapa gejala alamiah, tapi yang secara rumit terjalin dalam suatu dongeng, sedemikian sehingga gejala-gejala itu tersembunyi atau malah terhapuskan.

Sedemikian rumitnya untuk dipahami secara ilmiah, dengan cara pandang berbagai macam teori modern, namun sejarah telah mencatat bahwa mitos telah banyak memberikan kontribusinya terhadap peradaban umat manusia, terutama ketika mitos diposisikan sebagai salah satu sumber nilai, atau sebagai pembentuk tatanan kemasyarakatan pada zamannya.

"Dalam sejarah manusia, negara - dalam bentuk yang seperti sekarang - adalah hasil lebih kemudian dari proses peradaban. Jauh sebelum menciptakan negara sebagai satu bentuk organisasi sosial, manusia sudah melakukan berbagai percobaan lain untuk menata keinginan, perasaan, dan pemikirannya. Penataan dan sistematisasi seperti itu terjadi dalam bentuk bahasa, mitos, agama, dan kesenian" (Cassirer 1987).

La Galigo misalnya, mitos panjang yang lahir di tengah-tengah masyarakat Bugis, telah mencatatkan eksistensinya sepanjang sejarah masyarakat Bugis. La Galigo telah lama menjadi salah satu sumber nilai dalam kehidupan kebudayaan Bugis. Terdapat beberapa mitos lainnya dalam kebudayaan Bugis yang juga menjadi sumber nilai, misalnya mitos To Manurung dan mitos Arung Malasa Uli'e, tetapi epos La Galigo telah menjadi sumber nilai terbesar karena merupakan mitos agung yang dikeramatkan oleh kelompok masyarakat Bugis.

Dijadikan sebagai sumber nilai, karena teks La Galigo yang merupakan sajak naratif, meng- 
gambarkan episode-episode perjalanan kehidupan manusia dan lingkungannya, sangat memungkinkan untuk itu. Penggambaran tentang kehidupan individual dan sisoal, tentang sebuah sistem keyakinan, tentang tradisi masa silam, serta kemungkinan-kemungkinan di masa yang akan datang, semua tergambarkan dalam alur-alur yang tersusun secara apik dalam teks kuno tersebut.

Penggambaran tentang manusia yang lengkap itulah yang menjadikan naskah La Galigo dirujuk oleh para cendekiawan Bugis sebagai salah satu sumber dalam menguraikan tatanan nilai yang dianut oleh masyarakat Bugis, walaupun tidak menutup kemungkinan, hasil tafsiran para cendekiawan Bugis terhadap naskah $L a$ Galigo, memiliki kesamaan dengan tatanan nilai yang hidup pada kelompok masyarakat lain. Hal tersebut sangat mungkin terjadi, karena manusia hadir untuk membawa peradaban dengan budi yang melekat padanya, dan terdapat tatanan universal dalam diri manusia di mana pun dia hidup. Hanya saja ketika sebuah nilai yang dianggap sebagai nilai universal diterapkan, setiap kelompok masyarakat memiliki caranya masing-masing yang khas dalam penerapannya.

Nilai-nilai yang banyak terkandung dalam teks La Galigo, penyebarannya ke masyarakat dilakukan dengan berbagai macam cara dan secara turun temurun. Dalam tradisi masyarakat Bugis, ada jenis kesenian yang namanya massure,', sebuah kesenian yang pada awalnya merupakan tradisi lisan sebelum masyarakat Bugis mengenal tradisi tulis, kesenian inilah yang menjadi salah satu media penyebaran nilainilai yang terdapat dalam kitab La Galigo.
Kesenian ini berupa pembacaan syair yang terdapat dalam kitab La Galigo, pembacaan syair yang dilagukan hanya pada waktu-waktu tertentu. Kesenian massure' ini terdiri dari dua jenis, yaitu massure' toriolo dan massure' selleang.

"Pembacaan teks La Galigo dalam kesenian massure' memiliki struktur irama yang tidak monoton, sangat sesuai dengan fungsinya sebagai teks ritual, baik untuk massure' toriolo (membaca sebagaimana cara leluhur, yakni membaca dengan nada datar), maupun untuk massure' selleang (dilagukan), yang merupakan bentuk lazim penyajian teks tersebut di depan umum" (Pelras, 2006: 237).

Bentuk kesenian ini biasanya dilaksanakan ketika ada ritual-ritual tertentu, misalnya ritual dalam siklus kehidupan manusia, yaitu perkawinan, kelahiran dan kematian, serta sering juga dilaksanakan di tengah-tengah upacara atau ritual naik rumah baru. Karena sifatnya yang sakral atau dikeramatkan, maka teks La Galigo diperlakukan secara istimewa, tidak setiap upacara adat ada pembacaan teks La Galigo dalam bentukyang dilagukan atau massure'.

La Galigo, selain menjadi sumber nilai etis bagi masyarakat Bugis, juga sarat dengan nilainilai estetis yang kemudian menjadi sumber acuan estetis bagi seniman-seniman tradisional Bugis, walaupun mereka mungkin tidak paham dengan konsep estetika modern. Ketidakpahaman mereka dengan konsep estetika modern bukan berarti bahwa mereka atau masyarakat tradisional pada umumnya tidak memiliki konsep estetika dalam berkesenian, Sumardjo (2006: 91) menyebutnya, estetika mereka adalah estetika imani, sebuah konsep estetika 
yang berusaha menghadirkan sesuatu yang transenden dalam dunia manusia, tidak terlihat namun dipercaya sebagai suatu realitas, sesuatu itulah yang ingin digambarkan dengan simbolsimbol seni.

Selain kesenian massure', masyarakat Bugis juga memiliki kesenian massinrili' dan makkacaping, kedua kesenian tersebut adalah bentuk kesenian tradisional yang juga menjadi media dalam penyebaran nilai-nilai budaya di tengah msayarakat Bugis. Massinrili' adalah kesenian yang menggunakan alat musik gesek sejenis rebab yang bagi masyarakat Bugis menyebutnya dengan sinrili', namun dalam kitab La Galigo disebut talinroara. Sedangkan makkacaping adalah kesenian yang menggunakan alat musik petik yang disebut kacapiatau kecapi. Kedua jenis kesenian ini pada dasarnya mengiringi jalannya cerita yang dibawakan sendiri oleh pemusik sinrili' atau kacapi, dan syairnya diambil dari cerita-cerita rakyat yang banyak tersebar di masyarakat, misalnya dimabil dari Pau-pau rikadong. Pau-pau rikadong ini berupa cerita rakyat yang dituturkan, jika ingin disepadankan maka pau-pau rikadong bisa disebut sebagai dongeng masyarakat Bugis.

Dalam khasanah kebudayaan Bugis, masih terdapat banyak jenis kesusastraan yang merupakan sumber nilai selain kitab La Galigo, baik sastra yang disakralkan maupun sastra profan. Jenis-jenis kesusastraan yang lain tersebut misalnya, tolo', elong, sabo', memmang, dan berbagai jenis kesusastraan lainnya yang memiliki fungsifungsi, sebagai ritual maupun sebagai media bagi masyarakat untuk mengetahui nilai-nilai budaya mereka, ataupun sebagai kesenian yang berfungsi sebagai sarana hiburan masyarakat.
Saat ini, walaupun masih ada di kalangan masyarakat Bugis yang mensakralkannya, kitab La Galigo tidak lagi dijadikan sebagai sebuah kitab ritual, tetapi telah menjadi kitab yang kandungan nilai-nilainya telah banyak digali melalui ilmu pengetahuan, misalnya melalui antropologi, hukum, sastra, dan sosiologi. Telah banyak tercatat ilmuwan dunia yang berkonsentrasi meneliti kitab kuno tersebut demi kepentingan ilmu pengetahuan, termasuk para ilmuwan Bugis sendiri, yang telah banyak melahirkan karya ilmiah dengan objek penelitian kitab La Galigo.

\section{Nilai-nilai Utama dalam Kebudayaan Bugis-Makassar}

\section{Lempu'}

Lempu', jika diartikan secara etimologis berarti lurus, namun jika dikaitkan dengan nilainilai yang terdapat dalam kebudayaan Bugis maka kata lempu' akan bermakna kejujuran. Kejujuran merupakan salah satu nilai utama dalam kebudayaan Bugis, yang menuntut masyarakat Bugis untuk bertindak dan berkata jujur pada setiap langkah dalam kehidupannya, khususnya kejujuran pada hal-hal yang berkaitan dengan hukum dan harta benda.

Lempu adalah nama lain dari bunga nangka dalam bahasa Bugis, selain wunga panasa, yang kemudian dijadikan sebagai simbol kejujuran dalam sebuah ungkapan berbahasa Bugis, "duwami uwala sappo, wunga panasa na belo kanuku", hanya dua yang aku jadikan pagar, bunga nangka dan hiasan kuku.

Wunga panasa atau bunga nangka dijadikan simbol dalam ungkapan ini, karena selain ber- 
nama wunga panasa, dalam bahasa Bugis bunga nangka disebut juga dengan lempu, yang berasosiasi bunyi dengan lempu', yang jika dibawa ke dalam konteks moral maka lempu atau lempu' akan bermakna kejujuran. Kemudian yang menjadi hiasan kuku atau belo kanuku adalah daun pacar (lawsonia inermis) atau dalam bahasa Bugis disebut dengan pacci atau paccing. Pacci yang dalam aksara Bugis berasosiasi bunyi atau sering juga dibaca dengan paccing, bermakna bersih atau suci. Dua kata itulah yang kemudian dijadikan sebagai simbol kejujuran dalam budaya Bugis-Makassar, lurus dan bersih, malempu' na mapaccing.

\section{Getteng}

Getteng adalah sebuah nilai dalam budaya Bugis yang bermakna keteguhan, konsisten dan ketegasan dalam memegang prinsip yang diyakini. Jika berbicara tentang nilai, tentunya yang dibicarakan adalah prinsip-prinsip kehidupan yang bermakna positif. Getteng atau keteguhan masyarakat Bugis misalnya, tentunya yang dimaksud adalah keteguhan masyarakat Bugis dalam memegang prinsip-prinsip kebenaran. Seperti yang dijelaskan Rahim (1992: 161) dalam bukunya: Selain berarti teguh, kata getteng berarti tetap-azas atau setia pada keyakinan, atau kuat dan tangguh dalam pendirian, erat memegang sesuatu. Sama halnya dengan nilai lempu', nilai ada tongeng dan nilai reso, nilai keteguhan atau getteng terikat pada makna yang positif. Sikap getteng ini antara lain dipraktekkan dalam proses penegakan hukum yang tidak pandang bulu, sehingga lahir sebuah ungkapan Bugis yang mengatakan, ade'e temmakkeana', temmakke eppo, hukum tidak beranak dan tidak bercucu.

Praktek penegakan hukum yang tegas seperti itu pernah dipraktekkan oleh seorang cendekiawan Bugis bernama La Pagala Nene' Mallomo (1546 - 1654), yang bertindak sebagai hakim kerajaan di Sidenreng, memberikan hukuman mati kepada putra kandungnya sendiri, karena telah mengambil sebatang kayu milik tetangganya tanpa seizin sang pemilik, untuk mengganti sisir bajaknya yang rusak Ketika hukuman itu dijatuhkan, masyarakat menyesalkan tindakan Nene' Mallomo yang menjatuhkan hukuman mati kepada anaknya sendiri yang hanya mengambil sebatang kayu milik tetangganya. Nene' Mallomo kemudian dengan tegas menjawab penyesalan masyarakatnya dengan mengatakan, ade'e temmakkeana', temmakke eppo.

\section{Ada Tongeng}

Ada tongeng, jika diartikan ke dalam bahasa Indonesia akan berarti ucapan yang benar. Ucapan yang benar, dalam hal ini adalah ucapanucapan yang tidak mengandung kebohongan atau kata-kata dusta dan senantiasa mengucapkan kata-kata yang baik dan benar, atau dengan kata lain memelihara mulut agar tidak mengucapkan kebohongan atau dusta kepada orang lain atau di hadapan hukum. Selalu berkata benar, yang dimaksudkan ialah yang memelihara mulut sehingga tidak mengucapkan kata-kata dusta, sekalipun kedustaan itu tidak diketahui oleh seorang pun (Ibrahim, 2003: 46). Dalam nilai-nilai budaya Bugis, ada tongeng 
menjadi salah satu nilai utama, wajib dimiliki dan dipegang teguh oleh setiap manusia.

Nilai ada tongeng bukan sekedar sebuah ucapan atau kata-kata yang benar, tetapi jauh lebih luas dari sekedar sebuah ucapan atau katakata. Ada tongeng tidak bisa dipisahkan dengan ya ada ya gau', ucapan yang benar yang dibuktikan dengan perbuatan yang benar pula. Ketika seseorang mengucapkan kata-kata yang benar, tentunya harus juga diikuti dengan perbuatan yang sesuai dengan ucapannya, tidak hanya sampai pada ucapan atau kata-kata yang dianggap benar.

Penerapan nilai ada tongeng dalam realitas kehidupan sangat erat kaitannya dengan penegakan hukum. Ketika masyarakat umum dituntut untuk memegang teguh nilai ada tongeng, maka tuntutan tersebut tidak memiliki pengecualian terhadap para pabbicara atau penegak hukum, bahkan para pabbicara dituntut untuk lebih teguh dalam memegang nilai ada tongeng tersebut, agar hukum mampu berbicara benar dalam mengambil keputusan. Ada tongeng merupakan salah satu dari bagian kesadaran hukum masyarakat Bugis selain getteng, lempu'dan siri'.

\section{Reso}

Ketika berharap mencapai sesuatu tanpa reso maka hal itu hanyalah sebauh mimpi, namun jika telah berani bermimpi maka harus berani bekerja keras, karena hanya dengan kerja keraslah yang akan mendatangkan rahmat Yang Maha Kuasa. Masyarakat Bugis yang sangat mempercayai adanya campur tangan kekuatan adi-kodrati dalam proses perjalanan kehidupan dunia empiris ini, yang kemudian memunculkan etos kerja yang didasari oleh nilai reso.

Reso, salah satu nilai utama dalam kebudayaan Bugis, merupakan nilai yang lebih bersifat praksis dalam proses pencapaian tujuan dalam kehidupan, misalnya tujuan ekonomis, karir, pendidikan dan berbagai tujuan hidup lainnya. Reso bermakna kerja keras, tetapi ada juga kalangan budayawan Bugis yang mengartikannya dengan usaha. Dalam banyak pepatah klasik Bugis, reso atau kerja keras lebih banyak dihubungkan dengan pencapaian tujuan ekonomis atau kesuksesan hidup pada bidang ekonomi.

Sebagai salah satu nilai utama, reso merupakan nilai yang menjadi akar dari etos kerja yang terdapat dalam diri masyarakat Bugis, yang kemudian dijadikan sebagai inspirasi untuk mencapai tujuan hidup yang dicita-citakan. Reso tidaklah berdiri sendiri semata-mata sebagai sebuah usaha manusia, tetapi reso juga tetap meniscayakan kehadiran atau campur tangan kekuatan adi-kodrati. Hal tersebut terlihat jelas dalam sebuah ungkapan klasik Bugis yang mengatakan, reso pa na tinulu temmangingngi, na malomo naletei pammase dewata, hanya dengan kerja keras yang tekun tanpa bosan, yang akan memudahkan datangnya rahmat Yang Maha Kuasa.

Energi yang terdapat dalam ungkapan tersebut di atas selanjutnya membangun sebuah kekuatan dari dalam diri masyarakat Bugis yang disebut etos kerja, yang kemudian menjadi pendorong untuk tidak berhenti berusaha sebelum mencapai apa yang dicita-citakannya. 
Kegigihan dalam bekerja tersebut didasari oleh sebuah pandangan yang disebut were, dan nilai were ini yang membuat mereka tidak mudah menyerah pada nasib. Were mengajarkan bahwa nasib seseorang tidak akan berubah tanpa kerja keras dengan semangat juang yang tidak kenal lelah (Abidin, 1999: 183).

\section{Siri' dan Pesse sebagai Nilai Dasar}

Siri', bagi masyarakat Bugis-Makassar adalah dirinya, adalah manusia itu sendiri, sesuatu yang sangat mendasar dalam tatanan kehidupan mereka. Siri' adalah jiwa bagi masyarakat BugisMakassar, sehingga lahir sebuah ungkapan dalam bahasa Bugis yang mengatakan "Siri" emmitu na toriaseng tau. Narekko de'na siri'ta, taniani' tau, rupa tau mani asenna", yang arti bebasnya kurang lebih demikian, "karena siri' lah maka kita disebut manusia, ketika kita tidak memiliki siri' lagi, maka kita bukan lagi manusia, tetapi hanya menyerupai manusia". Sebuah ungkapan yang memandang siri' sebagai suatu simbol kemanusiaan.

Siri' jika hanya dilihat secara etimologis, maka siri' itu berarti malu atau rasa malu. Mangemba (1977) pada makalah ceramahnya yang berjudul "Siri' dalam Pandangan Orang Makassar", mencoba mengemukakan bahwa kata siri' adalah bermakna kehormatan, harga diri, martabat atau dignity apabila dilihat dari pengertian kulturalnya. Senada dengan penyataan Mangemba, Mattulada (1995: 341) mengemukakan, bahwa siri' itu tidak lain dari pada martabat dan harga diri manusia. Tetapi jika mencoba melihatnya lebih dalam, maka siri' itu adalah roh bagi masyarakat Bugis-Makassar, sebuah entitas yang menghidupkan, memanusiakan, bukan sekedar arti yang melekat padanya, tetapi sebuah makna yang senantiasa memberikan kehidupan.

Pada dasarnya dunia realitas manusia lebih banyak dipengaruhi oleh perilaku kebiasaan, perilaku atau tindakan yang sudah terbiasa atau telah umum dilakukan oleh orang banyak. Ketika sebuah perilaku, yang secara etis dianggap tidak beretika atau kurang memiliki nilai etis, namun dilakukan secara berulang-ulang oleh orang banyak, maka perilaku tersebut cenderung dianggap sebagai sebuah kebenaran, atau bahkan lebih parah lagi jika dianggap sebagai sebuah nilai etis yang baru atau budaya yang baru. Sebuah kebiasaan tidak bisa serta merta dianggap sebagai sebuah kebenaran, walaupun telah umum dilakukan oleh masyarakat, karena hal tersebut akan menghancurkan nilai-nilai kemanusiaan.

"Aapabila pangngaderreng adalah kebiasaan atau aturan-aturan yang sudah dibiasakan saja, maka akan hilanglah satu aspek yang terdapat dalam hakekat pangngaderreng, yaitu memelihara dan menumbuhkan harkat dan nilai-nilai insani, yang justru menjadi tulang punggung untuk tegaknya pangngaderreng. Kebiasaan atau aturan-aturan adat yang dibiasakan, malahan dapat menjerumuskan harkat dan martabat manusia ke dalam jurang kebinasaan" (Mattulada, 1995: 340).

Pangngaderreng itu sendiri adalah sebuah tatanan yang meliputi seluruh kegiatan hidup, bertingkah laku dan termasuk juga di dalamnya aturan adat dan sistem norma dalam kehidupan manusia. Hal tersebut tidak jauh berbeda dengan yang diuraikan Mattulada (1995: 339), pangngaderreng adalah wujud kebudayaan yang selain mencakup pengertian sistem norma dan aturanaturan adat serta tata tertib, juga mengandung 
unsur-unsur yang meliputi seluruh kegiatan hidup manusia, bertingkah laku dan mengatur prasarana kehidupan berupa peralatan-peralatan materil dan non materil. Pangngaderreng selanjutnya mendapatkan kekuatannya dari siri', sebagai nilai esensil dari manusia.

Siri' bukanlah sekedar sebuah kebiasaan, atau sekedar aturan-aturan adat yang dibiasakan, tetapi sebuah tatanan yang menghidupkan dan menjunjung harkat kemanusiaan. Jika ada kalangan yang memandang siri' hanya sekedar aturan-aturan adat atau sekedar sebuah kebiasaan, maka hal itulah yang dimaksud oleh Mattulada, yang menjerumuskan harkat dan martabat manusia ke dalam jurang kebinasaan.

Apakah setiap persoalan yang dihadapi oleh masyarakat Bugis-Makassar selalu diakhiri dengan tindak kekerasan atas nama nilai siri? Jawabannya adalah tidak harus selalu terjadi, karena siri' adalah sebuah tatanan yang senantiasa memiliki berbagai macam solusi terhadap persoalan yang dihadapi masyarakatnya. Ketika sebuah tindak kekerasan terjadi, lalu dengan serta merta memandangnya sebagai tindakan siri', tentunya hal tersebut adalah sebuah kekeliruan pandangan, itu bukanlah siri', melainkan akibat yang ditimbulkan oleh penegakan nilai siri'yang terlanggar.

Sebagai sebuah tatanan, siri' kemudian menjelma menjadi sebuah alat kontrol bagi masyarakat Bugis-Makassar dalam menjalani kehidupannya. Masyarakat Bugis-Makassar yang sejati adalah manusia yang menjadikan siri' sebagai alat kontrol dalm berperilaku, dan senantiasa berpikir, bahwa jika dirinya memiliki siri', maka manusia lain pun pasti memilikinya.
Hal demikian itulah yang seharusnya menjadi dasar gerak dalam berperilaku setiap individu untuk saling memanusiakan.

Pola perilaku masyarakat Bugis-Makassar dalam realitas kehidupan mereka, senantiasa menampakkan perwujudan dari unsur budaya mereka yang dikenal dengan nama siri' tersebut, seperti yang diungkapkan oleh Hamid Abdullah dalam bukunya.

"Dalam kehidupan masyarakat BugisMakassar, siri' merupakan unsur yang prinsipil dalam diri mereka. Tidak ada satu nilai pun yang paling berharga untuk dibela dan dipertahankan di muka bumi ini selain daripada siri'. Bagi masyarakat Bugis-Makassar, siri' adalah jiwa mereka, harga diri mereka dan martabat mereka. Sebab itu, untuk menegakkan dan membela siri' yang dianggap tercemar atau dicemarkan oleh orang lain, maka masyarakat Bugis-Makassar akan bersedia mengorbankan apa saja, termasuk jiwanya yang paling berharga demi tegaknya siri' dalam kehidupan mereka" (Abdullah, 1985: 37).

Kata siri' itu sendiri telah disebutkan dalam naskah La Galigo, pada episode awal, yaitu episode mula tau atau episode ketika La Toge' Langi' Batara Guru sebagai Tomanurung akan diturunkan ke dunia tengah atau ale kawa', namun kata siri' dalam naskah tersebut masih berupa simbol yang memerlukan penafsiran. Dalam teks La Galigo, kata siri' masih mengacu pada sejenis tumbuhan yang saat ini dikenal dengan daun sirih (Piperis Betle Folium). Ketika itu Patoto'e berpesan kepada Batara Guru, putra sulungnya, yang akan diturunkan ke bumi, untuk membawa beberapa jenis benda, termasuk di dalamnya daun sirih. 
Tiwi' ko ana' taletting mperre,

siri atakka, telle' araso,

le wempong mani, wenno' rakkile' to Leteng

Nriu',

le cucubanna to Sawang Kuttu.

Nae rekkua Batara Guru

le mattengnga no nonno' ri Kawa'

akkeppeang no taletting mperre'

naia nonno' mancaji tana,

mpujung lolangeng nakemmo bulu',

mpujung tanete pawekke' tana,

pakkenna tasi' taro tappareng,

curi' walenna, palekko salo',

napassarasa linrung smudda.

Addaukeng no siri atakka ri ataummu

telle' araso ri abeomu.

Ia na ritu mancaji ale'

Artinya:

... Bawalah wahai anakku, taletting mperre', siri atakka, telle' araso, wempong mani, bertih kilat orang Leteng

Nriu', beras berwarna dari Sawang Kuttu.

Bila engkau, Batara Guru,

di tengah perjalanan turun ke bumi

lemparkanlah taletting mperre'

agar ia turun menjadi tanah,

membentuk tempat hunian

mengonggokkan gunung,

membentuk pebukitan memperluas tanah,

menghamparkan laut meletakkan danau,

menoreh binanga, membelokkan sungai

dan membuat serasah di balik samudra.

Lemparkanlah siri atakka di sebelah

kananmu,

telle' araso di sebelah kirimu.

Itulah yang akan menjadi hutan.

(Toa, 1995: 114-117).

Matthes dalam Marzuki (1995: 36) menjelaskan, bahwa nama tanaman yang dilambangkan sebagai bali atakka atau pasangan tanaman atakka yang disebutkan dalam naskah La Galigo yaitu siri, adalah tidak lain dari tanaman sirih.
Sirih, yang menjadi bahan penganan sirihpinang pada prosesi penyambutan tamu-tamu kehormatan pada istana kerajaan-kerajaan di Nusantara ini.

"Nama tanaman siri yang disebut dalam Sure' Selleang I La Galigo merupakan pelambang terhadap kata siri'. Dikemukakan, bahwa hutan-hutan belantara (ale'-ale') yang dinyatakan sebagai penjelmaan tanaman siri merupakan pelambang bagi kehidupan di dunia tengah (ale kawa)" (Salahuddin dalam Marzuki, 1995: 103).

Siri atakka itulah yang dibawa dan kemudian dilemparkan oleh Batara Guru di tengah perjalanannya menuju ale kawa', yang merupakan sumber terciptanya ale' atau hutan. Hutan dalam hal ini danggap sebagai simbol kehidupan, karena hutan merupakan sumber kehidupan bagi berbagai jenis makhluk hidup, termasuk juga manusia. Makhluk hidup tentunya memiliki ketergantungan yang sangat tinggi terhadap keberadaan hutan. Itulah sebabnya kenapa hutan menjadi salah satu hal yang sangat penting, sehingga proses penciptaannya berlangsung sebelum Batara Guru sampai ke ale kawa'.

Dalam konsep siri' itu sendiri, terdapat istilah masseddi siri', artinya penyatuan siri' suatu kelompok dalam masyarakat Bugis-Makassar yang masing-masing anggotanya memiliki kedekatan secara emosional dalam kehidupan mereka, yang secara kolektif menegakkan siri' bersama. Masing-masing dari setiap anggota kelompok memiliki kewajiban untuk saling menjaga dan menegakkan siri'kelompoknya.

Masseddi siri', yang mendekatkan individuindividu secara emosional manjadi sebuah 
komune dalam masyarakat, terbentuk secara alami dengan dua jenis pola. Pola pertama yaitu, mereka membangun kebersamaan karena adanya kedekatan secara genealogis, dan pola yang kedua adalah karena adanya kedekatan mereka secara sosiologis.

Pola yang pertama adalah pola genealogis. Dengan pola genealogis ini masyarakat BugisMakassar merasa masseddi siri' dengan anggota yang lainnya karena adanya hubungan darah. Terdapat beberapa unsur dalam pola ini yang menjadi pengikat dalam konsep masseddi siri'. Unsur-unsur yang menjadi pengikat masseddi siri' dalam pola genealogis adalah kekerabatan, dan yang lainnya adalah karena arajang atau pusaka dalam sebuah keluarga besar. Karena mereka merasa memiliki hubungan kekerabatan dan merasa memiliki bersama suatu pusaka, yang harus mereka jaga, maka hal itulah yang kemudian mengikat mereka dalam ikatan masseddi siri' tersebut

Sistem kekerabatan dalam masyarakat Bugis-Makassar yang menganut sistem kekerabatan bilateral, yaitu sistem kekerabatan yang memperhitungkan hubungan kekerabatan dari kedua belah pihak, pihak ibu dan pihak ayah, memungkinkan seseorang memiliki ikatan masseddi siri' dengen dua komune. Sistem kekerabatan semacam ini, menjadikan seorang anak dalam masyarakat Bugis-Makassar tidak hanya terikat dalam kekerabatan satu pihak saja, tetapi terikat serta menjadi anggota kerabat dari keluarga besar ibunya maupun keluarga besar ayahnya. Sistem semacam ini kemudian mengikat si anak dalam kebersamaan siri' dengan pihak kerabat ibu dan ayahnya.
Pola yang kedua adalah pola sosiologis. Pola sosiologis mempersatukan individu-individu dalam ikatan masseddi siri' karena adanya hubungan-hubungan sosial yang membangun kedekatan mereka secara emosional. Masseddi siri' yang terbangun dalam pola sosiologis menemukan bentuknya ketika diikat dalam unsurunsur, hierarki, teritori, dan perkawinan.

Hierarki sebagai unsur pembentuk ikatan masseddi siri'. Ketika rakyat dan seorang raja telah membuat kontrak politik atau sebuah kesepakatan politik untuk memimpin dan dipimpin, maka ketika itu pulalah telah terjadi kesepakatan untuk mengikatkan diri masingmasing dalam ikatan masseddi siri', Raja wajib menjaga dan melindungi siri' rakyatnya dan begitu pula sebaliknya, rakyat wajib menjaga siri' rajanya. Hierarki semacam ini adalah hirarki politik yang sifatnya formal, yang dimanfaatkan sebagai alat, untuk saling menjaga dan melindungi demi mencapai kesejahteraan bersama dalam ikatan masseddi siri'.

Selain hierarki politik, dalam masyarakat Bugis-Makassar dikenal adanya hierarki dalam bentuk ajjoareng, atau yang dalam kajian antropologis dikenal dengan istilah patronase. Hubungan dalam sistem ajjoareng ini bersifat instrumental, seorang individu dalam posisi sebagai klien atau joa' menjalin hubungan dengan seorang individu lainnya dalam posisi sebagai patron atau ajjoareng, berdasarkan kepentingan atau kebutuhan. Klien memiliki kepentingan atau kebutuhan terhadap patronnya. Begitu pula sebaliknya, patron memiliki kebutuhan atau kepentingan terhadap kliennya. Antara patron dan klien masing-masing saling 
membutuhkan, walaupun di antara mereka terdapat ketidakseimbangan antara pemberian dan penerimaan. Dalam hal ini, apa yang telah diberikan oleh patron kepada kliennya jauh lebih besar dibanding apa yang telah diterima oleh patron dari kliennya. Jika melihat konteks Sulawesi Selatan, pada umumnya yang menjadi patron adalah para bangsawan, atau arung dalam bahasa Bugis, karaeng dalam bahasa Makassar.

Komune dalam sistem patronase ini selanjutnya mengikat mereka juga dalam ikatan masseddi siri'. Antara patron dan klien wajib untuk saling menjaga dan menegakkan siri', diantara mereka telah tumbuh kesatuan siri karena adanya hubungan yang sangat erat di antara mereka. Ahimsa-Putra (2007: 18) mengatakan, antara karaeng dengan pengikutnya telah ada kesatuan siri', sehingga gangguan terhadap yang lain akan ditanggapi sebagai gangguan terhadap dirinya pula. Perlindungan seorang karaeng akan diimbangi dengan kesetiaan dari pihak kliennya atau joa'-nya.

Teritori atau sebuah wilayah adalah salah satu unsur yang menjadikan individu-individu di dalamnya merasa menjadi sebuah keluarga besar, walaupun tanpa ada hubungan darah. Teritori yang dimaksud disini bukan sekedar sebuah wilayah politik sebuah kerajaan, atau sekedar sebuah wilayah administratif, tetapi sebuah wilayah adat yang menjadi tempat yang disucikan bagi masyarakat tradisional BugisMakassar. Tempat semacam itu merupakan tempat ritual bagi mereka yang masih mempraktekkan ritual-ritual tradisional, yang dalam bahasa Bugis biasa disebut dengan turungeng. Satu turungeng biasanya dimiliki oleh se- kelompok masyarakat, namun mereka tidak terikat oleh wilayah-wilayah politik dan administratif. Terkadang ada individu dalam satu kelompok turungeng yang tinggal di daerah lain tetapi memiliki turungeng di suatu wilayah yang bukan tempat tinggalnya. Turungeng inilah yang menjadi pengikat bagi anggotanya dalam ikatan masseddi siri'. Namun tidak menutup kemungkinan, wilayah politik atau wilayah administratif dijadikan sebagai pengikat dalam ikatan masseddi siri', khususnya bagi masyarakat modern, yang menggunakan wilayah politik dan wilayah administratiftersebut.

Ketika dua individu mengikatkan diri dalam wadah perkawinan, maka keduanya pun telah bersepakat untuk mengikatkan diri dalam ikatan masseddi siri'. Karena perkawinan merupakan sebuah gejala sosial, maka ikatan masseddi siri dalam perkawinan tergolong dalam pembentukan masseddi siri' dengan pola sosiologis. Seorang suami wajib menjaga siri' istrinya, dan sang istri pun wajib menjaga siri' suaminya. Dua individu ini membentuk ikatan masseddi siri' yang baru, namun masing-masing dari mereka tidak lepas dari ikatan masseddi siri' yang secara genealogis telah melahirkan dan membesarkan mereka. Bagi anak-anak yang akan mereka lahirkan, ikatan masseddi siri' yang mereka bangun tersebut akan menjadi ikatan masseddi siri genealogis.

Siri' kemudian, bagi masyarakat BugisMakassar, menjadi sebuah konsep tatanan kehidupan, yang menjadi pedoman dalam berperilaku dan membangun interaksi serta relasi, baik antar individu manusia maupun antar kelompok sosial. Karena itulah, maka siri' dalam nilai-nilai budaya Bugis-Makassar di- 
anggap sebagai nilai yang paling mendasar. Jika dijabarkan lebih jauh, maka konsep siri' akan melingkupi atau terurai menjadi nilai-nilai yang lain yang terdapat dalam budaya Bugis.

Mattulada (1995: 342) dalam bukunya yang berjudul Latoa menjelaskan, bahwa siri' inilah yang menjadi azas terdalam dari pada semua kegiatan manusia memperlakukan dirinya dalam aspek-aspek pangngaderreng. Siri' tidak lain dari inti kebudayaan Bugis-Makassar yang memberi daya hidup serta menjadi tenaga penggerak atas pangngaderreng yang merupakan perwujudan totalitas kebudayaan BugisMakassar.

Adapun pesse merupakan salah satu nilai utama dalam nilai-nilai budaya Bugis yang senantiasa disandingkan dengan nilai siri'. Ketika mengucapkan siri', maka pesse akan senantiasa menyertainya, siri' na pesse, keduanya tidak terpisahkan. Membicarakan konsep nilai siri' berarti konsep nilai pesse pun tidak akan ketinggalan untuk diuraikan sebagai sebuah kesatuan.

Pesse itu sendiri berarti perih atau pedih yang lebih sering dimaknai dengan perasaan empati. Andaya (1979: 367) memahaminya dengan to smart, poignant. Pada bukunya yang lain Andaya (1981: 368) mengatakan, a Bugis-Makassar concept of empathy with the members of one's community. Senada dengan Andaya, Pelras juga menguraikan konsep pesse dalam bukunya:

"Pesse, atau lengkapnya pesse babua, yang berarti ikut merasakan penderitaan orang lain dalam perut sendiri', mengindikasikan perasaan haru (empati) yang mendalam terhadap tetangga, kerabat, atau sesama anggota kelompok sosial. Hal ini me- lambangkan solidaritas, tak hanya pada seseorang yang telah dipermalukan, namun juga bagi siapa saja dalam kelompok sosial yang sedang dalam keadaan serba kekurangan, berduka, mengalami musibah, atau menderita sakit keras" (Pelras 2006: 252).

Pandangan Andaya dan Pelras tersebut di atas, yang memaknai pesse sebagai sebuah konsep empati yang hanya berlaku terhadap anggota pada sebuah komunitas, dibantah oleh Marzuki (1995: 133) yang mengatakan bahwa, hakikat pesse (pacce: Makassar) tidak lain dari pengungkapan empati solidaritas terhadap penderitaan orang lain. Konsep pesse (pacce: Makassar) memotivasi sikap nyata kesetiakawanan sosial suku bangsa Bugis-Makassar. Apa yang telah diungkapkan oleh Marzuki di atas, ingin mengatakan bahwa konsep pesse tidak hanya berlaku terhadap anggota komunitas, tetapi berlaku terhadap setiap manusia, atau terhadap orang lain di luar komunitas.

Konsep pesse juga merupakan dasar pijakan dari konsep sipakatau dalam nilai-nilai budaya Bugis, selain konsep siri', karena konsep pesse berfungsi sebagai penggalang solidaritas, kebersamaan serta pemuliaan terhadap nilai-nilai kemanusiaan. Jadi konsep pesse tidak hanya berlaku terhadap anggota komunitas, tetapi berlaku terhadap setiap manusia, seperti yang dicontohkan oleh Marzuki (1995: 132): ketika ada seorang pendatang yang tidak dikenal, yang menderita kelaparan atau terancam bahaya musuh, lalu meminta uluran tangan, niscaya diterima serta diperlakukan sama dengan sanak keluarga sendiri, dan rela berbuat guna melindungi serta membela orang yang terancam itu, sekalipun nyawa dipertaruhkan. 
Ketika seseorang datang meminta uluran tangan, seperti yang dicontohkan di atas, maka siri' atau aib dan terinjak harga dirinya, bagi tuan rumah atau orang yang dimintai uluran tangan jika tidak mau membantu orang yang kesusahan. Membantu orang yang berada dalam kesulitan merupakan keharusan dan hal tersebut merupakan harga diri atau siri' yang harus ditegakkan.

Perasaan perih dan pedih atau empati melihat penderitaan orang lain itulah yang disebut dengan pesse. Sebuah konsep solidaritas kemanusiaan atau konsep humanitas yang terdapat dalam nilai-nilai budaya, dan telah lama dikenal oleh masyarakat Bugis-Makassar.

\section{Relevansi Nilai Siri' dan Pesse terhadap Penguatan Nilai Kebangsaan}

Indonesia dikenal sebagai salah satu negara yang didiami oleh berbagai macam etnis, dan memiliki keragaman budaya, bahasa serta kepercayaan. Etnis-etnis yang hidup di Indonesia mendiami jajaran kepulauan yang berderet dari Timur ke Barat. Indonesia jelas adalah sebuah negeri multikultural. Bhinneka Tunggal Ika memuat idealitas multikulturalisme di Indonesia (Hardiman, 2011: 79). Berbagai macam etnis, budaya, bahasa, dan kepercayaan yang hidup berdampingan selama ini dianggap sebagai sebuah kekayaan, namun tidak dapat dinafikan jika yang dimaksud sebagai kekayaan tersebut sekaligus bisa menjadi sebuah ancaman, ketika yang dianggap sebagai kekayaan itu tidak dikelolah dengan tepat.

Keragaman etnis, budaya, bahasa dan kepercayaan memang tidak dapat disangkal se- bagai sebuah kekayaan yang dimiliki oleh Indonesia, tetapi kekayaan itu tidak boleh dianggap hanya sebagai sebuah keberuntungan, justru kekayaan tersebut berpotensi menjadi bumerang yang dapat menggerogoti nilai-nilai kemanusiaan di negeri ini, negeri yang merupakan salah satu negara yang memiliki penduduk terpadat di dunia. Penduduk Indonesia yang padat ini, hidup dalam kelompok-kelompok etnis yang cenderung masih bersikap primordial, tidak menganggap kelompok etnis lain sebagai entitas yang juga memiliki eksistensi. Jika sikap-sikap primordialisme semacam itu yang terpelihara dalam setiap kelompok etnis ataupun kelompok agama dan kepercayaan, maka hal tersebut akan menjadi pemicu tergerusnya nilai-nilai kemanusiaan di Indonesia, hal tersebut telah terbukti pada tragedi kemanusiaan yang terjadi di Ambon, Poso, Sampit dan di beberapa tempat lainnya di negeri ini. Hardiman (2011: 83) mengatakan, siklus kekerasan-kekerasan kolektif di negeri ini sudah mengisyaratkan perlunya mengambil sikap tepat terhadap kelompok-kelompok di dalam negeri multikultural ini.

Salah satu dari sekian banyak keragaman budaya yang dimiliki oleh Indonesia adalah nilai Siri' dan Pesse, yang merupakan nilai-nilai yang lahir dari falsafah kehidupan salah satu suku bangsa yang ada di negeri ini, falsafah kehidupan yang tetap ada hingga saat ini, walaupun telah banyak ditinggalkan oleh generasinya dan disalahtafsirkan, demi kepentingan pribadi. Walaupun demikian, nilai siri' dan pesse tetaplah sebagai sebuah nilai yang tidak berubah seiring berubahnya pembawa nilai siri' dan pesse tersebut. 
Justru nilai siri' dan pesse tetap menjadi kekayaan dalam keragaman negeri ini yang nilai-nilainya bisa dijadikan sebagai salah satu nilai pemersatu bangsa. Nilai siri' harusnya dipahami secara tepat, bahwa siri' adalah nilai budaya yang mempersatukan secara politis, bahwa masyarakat Indonesia adalah masyarakat yang masseddi siri', masyarakat yang dipersatukan oleh martabat dan harga diri sebagai bangsa yang memiliki eksistensi di tengahtengah masyarakat dunia. Pola relasi masseddi siri' ini sangat dibutuhkan oleh bangsa Indonesia untuk memperkuat nilai kebangsaan yang sempat terkoyak oleh perpecahan yang bernuansa SARA. Hal tersebut seharusnya tidak perlu terjadi ketika masing-masing kelompok menyadari bahwa bangsa Indonesia adalah bangsa yang memiliki nilai kebangsaan yang dibangun dari nuansa keberagaman.

Sangat disayangkan ketika masyarakat Indonesia yang telah lama dikenal sebagai masyarakat yang santun, harus terkoyak oleh perpecahan yang tidak beralasan, saling menghinakan dan saling meniadakan, seolah-olah tidak ada lagi sedikit pun rasa empati yang tersisa. Perpecahan di antara anak bangsa harus mulai dikikis, dengan menggunakan kearifan budaya yang sangat banyak dimiliki oleh masyarakat Indonesia. Bangsa Indonesia pada dasarnya adalah bangsa yang sangat kaya akan kearifanyang bersumber dari keragaman nilai budayanya, dan salah satunya adalah nilai pesse yang berasal dari kearifan lokal masyarakat Bugis-Makassar.

Nilai pesse bukanlah satu-satunya nilai yang bisa dijadikan sebagai nilai pemersatu bangsa di
Indonesia, tetapi nilai pesse merupakan salah satu nilai budaya yang memiliki relevansi yang kuat untuk membangun dan memperkuat nilai kebangsaan di Indonesia. Hal tersebut sangat beralasan, karenapesse adalah sebuah nilai yang melekat pada diri setiap manusia, nilai empati. Setiap manusia, ketika masih memiliki kesadaran sebagai entitas manusia, maka sifat empati masih akan tetap melekat dalam dirinya, sekecil apa pun itu. Pada dasarnya dengan adanya nilai pesse atau rasa empati tersebut, maka konflik di antara anak bangsa tidak perlu terjadi. Seharusnya bangsa ini mngedepankan nilai-nilai semacam ituuntuk memperkuat nilainilai kebangsaan Indonesia.

\section{Kesimpulan}

Siri' merupakan nilai paling mendasar dalam kehidupan masyarakat Bugis-Makassar, karena siri' merupaka unsur yang prinsipil dalam diri mereka. Siri' dianggap sebagai jiwa masyarakat Bugis-Makassar, yang menghidupkannya dan memanusiakannya, atau bisa juga dikatakan sebagai perwujudan diri masyarakat BugisMakassar.

Siri' kemudian menjadi nilai dasar dalam kebudayaan Bugis-Makassar, sebab jika dilihat dari sifatnya sebagai sebuah nilai, maka akan nampak bahwa siri' merupakan nilai utama yang mendasari nilai-nilai utama lainnya dalam kebudayaan Bugis-Makassar, demikian juga halnya dengan nilai pesse.

Nilai pesse juga dikatakan sebagai nilai dasar, karena nilai pesse merupakan nilai yang serangkai dengan nilaisiri', yang juga menjadi dasar yang sangat prinsipil dalam nilai-nilai 
budaya Bugis-Makassar. Nilai pesse akan turut dibicarakan ketika nilai siri' diungkapkan, karena kedua nilai tersebut merupakan nilai yang tidak bisa dipisahkan, dan menjadi dasar nilai-nilai utama lainnya. Pesse pada dasarnya adalah sikap empati yang mendalam pada diri masyarakat Bugis-Makassar, yang kemudian membentuk karakter mereka sebagai manusia yang memiliki kesetiakawanan sosial yang kuat.

Siri' dan pesse sebagai nilai dasar dalam kebudayaan Bugis-Makassar bisa dijadikan sebagai sebuah model untuk membangun dan memperkuat nilai kebangsaan di negeri ini, yang berbasis pada nilai-nilai kearifan lokal. Nilai siri' dan pesse sangat relevan terhadap upaya penguatan nilai kebangsaan di Indonesia. Hal tersebut tercermin dalam makna yang terkandung dalam nilai siri' dan pesse. Saling menghargai dan menghormati martabat dan harga diri setiap manusia, merupakan makna yang terkandung dalam nilai siri', serta membangun kesetiakawanan sosial sebagai pemaknaan terhadap nilai pesse. [

\section{Daftar Pustaka}

Abdullah, Hamid. 1985. Manusia Bugis Makassar: Suatu Tinjauan Historis terhadap Pola Tingkah Laku dan Pandangan Hidup Manusia Bugis Makassar. Jakarta: Inti Idayu Press.

Abidin, Andi Zainal. 1999. Capita Selecta Sejarah Sulawesi Selatan. Ujung Pandang: Hasanuddin University Press.

Ahimsa-Putra, Heddy Shri. 2007. Patron \& Klien di Sulawesi Selatan: Sebuah Kajian
Fungsional-Struktural. Yogyakarta: Kepel Press.

Andaya, Leonard Y. 1979. “A Village Perception of Arung Palakka and the Makassar War of 1666-1669." in Perception of the Past in South East Asia, ed. A. Reid dan D. Marr. Singapore: Asian Studies of Australia.

Andaya, Leonard Y. 1981. The Heritage of Arung Palakka. The Hague: Martinus Nijhoff.

Barthes, Roland. 2009. Mitologi. III. terj. Nurhadi dan A. S. Millah. Yogyakarta: Kreasi Wacana.

Cassirer, Ernst. 1987. Manusia dan Kebudayaan: Sebuah Esei Tentang Manusia. terj. A. A. Nugroho. Jakarta: PT. Gramedia.

Frondizi, Risieri. 2007. Filsafat Nilai. terj. C. A. Wijaya. Yogyakarta: Pustaka Pelajar.

Gunawan, Bondan. 2012. "Pilihan Jalan Kebudayaan Menuju Indonesia Raya." dalam Strategi Kebudayaan untuk Kedaulatan Bangsa, ed. M. Masrukhi dan N. W. Arimbi. Yogyakarta: KAGAMA.

Hardiman, F. Budi. 2011. Hak-Hak Asasi Manusia: Polemik dengan Agama dan Kebudayaan. Yogyakarta: Kanisius.

Ibrahim, Anwar. 2003. Sulesana, Kumpulan Esai Tentang Demokrasi dan Kearifan Lokal. Makasar: Lembaga Penerbitan Universitas Hasanuddin (Lephas).

Mangemba, H. D. 1977.“Siri' dalam Pandangan Orang Makassar."

Marzuki, Mohamad Laica. 1995. Siri': Bagian Kesadaran Hukum Rakyat Bugis-Makassar (Sebuah Telaah Filsafat Hukum). Ujung Pandang: Hasanuddin University Press.

Mattulada. 1995. Latoa, Suatu Lukisan Analitis terhadap Antropologi Politik Orang Bugis. 
Ujung Pandang: Hasanuddin University Press.

Pelras, Christian. 2006. Manusia Bugis. Jakarta: Nalar-Forum Jakarta-Paris.

Rahim, H. A. Rahman. 1992. Nilai-nilai Utama Kebudayaan Bugis. Ujung Pandang: Hasanuddin University Press.
Sumardjo, Jakob. 2006. Estetika Paradoks. Bandung: Sunan Ambu Press.

Toa, Arung Pancana. 1995. I La Galigo (Menurut Naskah NBG 188). ed. M. Salim dan F. A. Enre. Jakarta: KITLV Bekerjasama dengan Djambatan. 